\title{
Studies on the disturbance of glucuronide formation in infectious hepatitis
}

\author{
M. F. VEST and E. FRITZ
}

From the Children's Hospital, University of Basle, Switzerland

SYNOPSIS The ability of the liver to form glucuronides was measured in 10 patients with infectious $\vec{A}$ hepatitis. One test was done at the onset and another about four weeks later after the clinical $\dot{c}$ symptoms had disappeared. N-acetyl-p-aminophenol (N.A.P.A.) or acetanilide was administered $\stackrel{\infty}{+}$ in doses ranging from 10 to $20 \mathrm{mg}$. per $\mathrm{kg}$. body weight, either orally or by intravenous injection. $N$ N.A.P.A. is conjugated by the liver at the hydroxyl group and excreted in the urine as sulphuric and glucuronic acid conjugates. Total conjugated p-aminophenol, free N.A.P.A., and N.A.P.A. $\bar{D}$ glucuronide were estimated in the urine of our patients. In the blood the disappearance of N.A.P.A. (free form) and the formation of N.A.P.A. glucuronide were traced.

During the acute phase of hepatitis the excretion of total conjugated p-aminophenol and of N.A.P.A. glucuronide in the urine is lower than after recovery from the disease. Likewise free N.A.P.A. disappears more slowly from the circulation and the peak concentration of N.A.P.A. glucuronide in the serum remains lower at the onset of hepatitis than after clinical cure. These results indicate that glucuronide formation during the acute stage of infectious hepatitis is depressed, as are other transformation mechanisms, i.e., of hippuric acid.

Studies of the directly reacting bile pigments either by reversed phase column chromatography (Billing, 1955a) or by partition between different solvents (Schachter, 1959); Eberlein, 1960) have given some indications of a disturbance of glucuronide formation in hepatitis. In the initial stages of viral hepatitis, apart from free bilirubin, pigment II, which is identical with bilirubin diglucuronide (Billing, Cole, and Lathe, 1957), is often present in the serum in increased amounts. As hepatic cells progressively degenerate, the less polar pigment I (bilirubin monoglucuronide) almost always forms the major bile pigment component (Billing 1955b; Bollman, 1959). Studies by Bollman (1957) in hepatectomized dogs or after poisoning the liver of experimental animals by carbon tetrachloride showed that bilirubin monoglucuronide can be formed outside the liver, but bilirubin diglucuronide is formed only in the liver. The increased amounts of pigment $I$ in cases of hepatitis, therefore, suggest the presence of a secondary disturbance in the liver, so that the conjugation of bilirubin with glucuronic acid or the conversion of bilirubin monoglucuronide to the diglucuronide is incomplete (Billing and Lathe, 1958). Other trans- formation reactions, for instance, the conjugation $\stackrel{2}{\Rightarrow}$ of benzoic acid with glycine to form hippuric acid, are also decreased in hepatitis. It seemed justified therefore to explore further the possibility of a disturbance in glucuronide formation during hepatitis in a more direct way than is possible by investigating? serum bilirubin fractions.

There are many substances besides bilirubin which are conjugated with glucuronic acid in the liver so as 0 to make them more soluble and enhance their excre- $₹$ tion. We chose N-acetyl-p-aminophenol (N.A.P.A.)윽 for our tests. The use of a compound, which, after $>$ conjugation in the liver, is excreted in the urine, seemed advantageous in as much as its behaviour is $N$ not influenced by a disturbance of bile secretion. Such a disturbance without doubt exists during ${ }^{N}$ hepatitis and plays a role in the alterations of ${ }^{N}$ bilirubin metabolism.

\section{METHODS}

Ten children with infectious hepatitis aged $2 \frac{1}{2}$ months to 15 years were studied twice during the course of their $\overrightarrow{\mathbb{D}}$ illness. One test was made at the beginning of hepatitis, $\stackrel{\varrho}{\subseteq}$ in the first week after the appearance of symptoms. The 
test was repeated about four weeks later, after clinical cure and after other liver function tests gave normal results. Six patients were given intravenous injections of 10 to $20 \mathrm{mg}$. of N.A.P.A./kg. weight dissolved in distilled water at temperature $60^{\circ} \mathrm{C}$. and sterilized in an autoclave at $120^{\circ} \mathrm{C}$. for 12 minutes. The solution was kept at $37^{\circ} \mathrm{C}$. until use. The other four patients received 10 to $20 \mathrm{mg}$. of acetanilide per $\mathrm{kg}$. body weight orally. Acetanilide is rapidly oxidized to N.A.P.A., which is then conjugated in the liver at the hydroxyl group. As will be shown, this hydroxy-conjugate is present in the serum almost exclusively in the form of N.A.P.A. glucuronide. However, apart from a small fraction of free N.A.P.A., it appears in the urine as N.A.P.A. glucuronide and -sulphate (Greenberg and Lester, 1946). After administration of the test substance urine was collected for a period of 24 hours in two separate 12-hour periods. Blood samples were drawn after 15 minutes and after one, two, three, four, six, or seven and sometimes nine hours and permitted to clot. Urine and serum were analysed for the free N.A.P.A., total conjugated p-aminophenol (consisting of $\mathrm{N}$-acetylp-aminophenol and hydroxy-conjugated $\mathbf{N}$-acetyl-paminophenol) and N.A.P.A. glucuronide. Free N.A.P.A. and total conjugated p-aminophenol were estimated by the methods of Brodie and Axelrod (1948). N.A.P.A. glucuronide was determined by measuring the amount of $\mathrm{N}$-acetyl-p-aminophenol liberated from serum or urine by the action of bacterial- $\beta$-glucuronidase. Enzymatic hydrolysis was carried out by adding $10 \mathrm{mg}$. of bacterial$\beta$-glucuronidase (Sigma Chemical Co.) to $1 \mathrm{ml}$. of serum or suitably diluted urine in $4 \mathrm{ml}$. of $0.15 \mathrm{M}$ acetate buffer, $p \mathrm{H} 6 \cdot 2$, and incubated at $37^{\circ} \mathrm{C}$. for 18 hours. The amount of N.A.P.A. glucuronide can be calculated by measuring free N.A.P.A. before and after hydrolysis (Vest and Streiff, 1959). The difference between total conjugated p-aminophenol and the sum of free N.A.P.A. and N.A.P.A. glucuronide represents N.A.P.A. sulphate.

In some cases the results were checked by independent estimation of glucuronides (Dische, 1947) and of sulphates (Folin, 1905) in the urine. The amounts of glucuronic acid and sulphate in the urine during the test period were compared with the average excretion of these substances during a control period, immediately before the administration of the test substance. Other liver function tests were done by standard methods.

\section{RESULTS}

EXCRETION OF N.A.P.A. METABOLITES IN THE URINE In Table I the excretion of total conjugated p-aminophenol in the early stages of hepatitis and after recovery is listed as a percentage of the dose of acetanilide or N.A.P.A. given. In all cases investigated total excretion was diminished during the acute phase. On the average it amounted to $60 \%$ during hepatitis and to $74.4 \%$ after cure. The latter value is identical with the average excretion found in normal children or adults. Only in early infancy is the percentage excretion lower because of immaturity of the liver (Vest, 1958). This is reflected in the low values found in the case of the $2 \frac{1}{2}$-month-old infant. There is no difference in the percentage excretion between the lower (10 mg. per $\mathrm{kg}$. body weight) or higher ( $20 \mathrm{mg}$. per $\mathrm{kg}$. body weight) dose of N.A.P.A. or acetanilide.

In column 5 of Table I the result of the first test is expressed as a percentage of the values found after recovery. From this it appears that the excretion during the acute phase of hepatitis was on the average only $81 \%$ of that reached after cure. Calculation of the significance of the difference between the two tests using the t test of Fisher (1954) shows that the observed decrease in percentage excretion is statistically highly significant, $P$ being $<0.001$.

The individual amounts of free N.A.P.A., of N.A.P.A. liberated by $\beta$-glucuronidase, and of other hydroxyconjugates (N.A.P.A.-sulphate) are listed in Table II for the six patients in whom these N.A.P.A. metabolites were individually estimated in the urine. The values given refer to the first 12-hour period after injection of N.A.P.A. They are expressed as a

TABLE I

EXCRETION OF TOTAL P-AMINOPHENOL AT ONSET OF HEPATITIS AND AFTER RECOVERY

\begin{tabular}{|c|c|c|c|c|c|}
\hline \multirow[t]{2}{*}{ Name } & \multirow[t]{2}{*}{ Age } & \multirow{2}{*}{$\begin{array}{l}\text { Substance and } \\
\text { Dosage (mg./kg.) }\end{array}$} & \multicolumn{2}{|c|}{ Percentage Excretion in 24 Hours } & \multirow{2}{*}{$\begin{array}{l}\text { Results of First Test } \\
\text { as } \% \text { of Second Test }\end{array}$} \\
\hline & & & $\begin{array}{l}\text { During Hepatitis } \\
\text { (First Test) }\end{array}$ & $\begin{array}{l}\text { After Recovery } \\
\text { (Second Test) }\end{array}$ & \\
\hline $\begin{array}{l}\text { B.G. } \\
\text { C.C. } \\
\text { S.N. } \\
\text { F.R. } \\
\text { R.M. } \\
\text { T.A. } \\
\text { M.H. } \\
\text { K.V. } \\
\text { K.A. } \\
\text { N.C. }\end{array}$ & $\begin{array}{l}2 \frac{1}{2} \mathrm{mth} . \\
5 \mathrm{yr} . \\
10 \mathrm{yr} . \\
3 \frac{1}{2} \mathrm{yr} . \\
15 \mathrm{yr} . \\
7 \mathrm{yr} . \\
10 \mathrm{yr} . \\
12 \mathrm{yr} . \\
14 \mathrm{yr} . \\
5 \mathrm{yr} .\end{array}$ & $\begin{array}{l}\text { Acetanilide } 10 \\
\text { Acetanilide } 10 \\
\text { Acetanilide } 20 \\
\text { Acetanilide } 20 \\
\text { N.A.P.A. } 10 \\
\text { N.A.P.A. } 10 \\
\text { N.A.P.A. } 10 \\
\text { N.A P.A. } 20 \\
\text { N.A.P.A. } 20 \\
\text { N.A.P.A. } 20\end{array}$ & $\begin{array}{l}40 \\
54 \cdot 6 \\
75 \\
42 \\
73 \\
51 \cdot 5 \\
73 \\
64 \cdot 5 \\
71 \cdot 7 \\
55\end{array}$ & $\begin{array}{l}46 \\
62 \cdot 5 \\
85 \\
63 \cdot 5 \\
86 \cdot 6 \\
81 \cdot 5 \\
93 \cdot 3 \\
84 \\
80 \cdot 4 \\
61\end{array}$ & $\begin{array}{l}87 \\
87 \cdot 7 \\
88 \cdot 2 \\
66 \cdot 1 \\
84 \cdot 3 \\
63 \cdot 2 \\
78 \cdot 3 \\
77 \\
89 \cdot 1 \\
90\end{array}$ \\
\hline Average & & & 60.0 & $74 \cdot 4$ & $81 \cdot 1$ \\
\hline
\end{tabular}


TABLE II

EXCRETION OF FREE N.A.P.A., N.A.P.A. GLUCURONIDE, AND N.A.P.A. SULPHATE DURING 12-HOUR PERIOD AFTER INJECTION OF N.A.P.A. AS PERCENTAGE OF AMOUNT ADMINISTERED

\begin{tabular}{|c|c|c|c|c|c|c|c|c|}
\hline \multirow[t]{3}{*}{ Name } & \multirow[t]{3}{*}{ Age } & \multirow{3}{*}{$\begin{array}{l}\text { Dosage of } \\
\text { N.A.P.A. } \\
\text { (mg./kg.) }\end{array}$} & \multicolumn{6}{|c|}{ Percentage Excretion in 12 Hours } \\
\hline & & & \multicolumn{2}{|c|}{$N$-acetyl-p-aminophenol } & \multicolumn{2}{|c|}{ N.A.P.A. Glucuronide } & \multicolumn{2}{|c|}{ N.A.P.A. Sulphate } \\
\hline & & & First Test & Second Test & First Test & Second Test & First Test & Second Tes \\
\hline $\begin{array}{l}\text { T.A. } \\
\text { M.H. } \\
\text { R.M. } \\
\text { N.C. } \\
\text { K.V. } \\
\text { K.A. }\end{array}$ & $\begin{array}{l}7 \mathrm{yr} . \\
10 \mathrm{yr} . \\
15 \mathrm{yr} \text {. } \\
5 \mathrm{yr} \text {. } \\
12 \mathrm{yr} \text {. } \\
14 \mathrm{yr} \text {. }\end{array}$ & $\begin{array}{l}10 \\
10 \\
10 \\
20 \\
20 \\
20\end{array}$ & $\begin{array}{l}3.0 \\
3.7 \\
2.5 \\
3.7 \\
4.5 \\
4.0\end{array}$ & $\begin{array}{l}6.2 \\
5.4 \\
2.8 \\
3.3 \\
4.0 \\
3.0\end{array}$ & $\begin{array}{r}4 \cdot 1 \\
24 \cdot 2 \\
28 \cdot 0 \\
19 \cdot 2 \\
33 \cdot 8 \\
40 \cdot 5\end{array}$ & $\begin{array}{l}39 \cdot 0 \\
43 \cdot 1 \\
50 \cdot 7 \\
24 \cdot 3 \\
39 \cdot 5 \\
37 \cdot 8\end{array}$ & $\begin{array}{l}34 \cdot 7 \\
43 \cdot 5 \\
35 \cdot 8 \\
16 \cdot 1 \\
19 \cdot 6 \\
20 \cdot 8\end{array}$ & $\begin{array}{l}25 \cdot 5 \\
40 \cdot 8 \\
20 \cdot 5 \\
26 \cdot 4 \\
35 \cdot 5 \\
32 \cdot 1\end{array}$ \\
\hline Average & & & 3.6 & $4 \cdot 1$ & $25 \cdot 0$ & 39.0 & $28 \cdot 5$ & $30 \cdot 0$ \\
\hline
\end{tabular}

percentage of the dose administered. It is evident that in contrast to the overall excretion of Table I there is some difference according to the dose used in testing the formation of conjugates. With regard to the excretion of N.A.P.A. glucuronides, all patients with one exception, K.A., excreted more N.A.P.A. as glucuronide in the second test than during the acute phase. Even in the case of K.A., the glucuronide content was higher in the second test, when the whole 24-hour urine specimen is considered instead of a 12-hour specimen. But the increase of N.A.P.A. glucuronide in the urine after recovery from hepatitis is distinctly higher in the groups of patients receiving $10 \mathrm{mg}$. per $\mathrm{kg}$. body weight of N.A.P.A. than in the three patients who were tested with $20 \mathrm{mg}$. per $\mathrm{kg}$. Because the sulphate conjugates are calculated as the difference between total excretion and the sum of free N.A.P.A. and N.A.P.A. glucuronide, they tend to show an inverse relationship to the glucuronides. Therefore, N.A.P.A. sulphate forms a bigger part of the total conjugates in the group receiving $20 \mathrm{mg}$. N.A.P.A. per $\mathrm{kg}$. than in the group with $10 \mathrm{mg}$. per $\mathrm{kg}$. Likewise in the individuals who received $20 \mathrm{mg}$. per kg., N.A.P.A. sulphate showed an increase after recovery, whereas in the group with only $10 \mathrm{mg}$. per $\mathrm{kg}$. it tended to be reduced. No persistent trend is evident in the excretion of free N.A.P.A., which rarely exceeds $5 \%$ 을 of the dose administered. On the average of all patients, free N.A.P.A. increased from $3.6 \%$ to $4.1 \%$, N.A.P.A. glucuronide from $25 \%$ to $39 \%$, and other

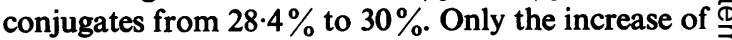
the glucuronides is statistically significant $(P=0.05)$.

DISAPPEARANCE RATE OF FREE N.A.P.A. AND FORMATION $\vec{\varphi}$ OF N.A.P.A. GLUCURONIDE IN BLOOD At the begin- $\stackrel{9}{\rightarrow}$ ning of the investigation it was presumed that in the blood, as in the urine, N.A.P.A. conjugates would consist of glucuronides and sulphates. However, a comparison between the total amounts of N.A.P.A. (estimated as p-aminophenol) in the same serum $\mathbb{D}$ sample after acid hydrolysis by hydrochloric acid at $120^{\circ} \mathrm{C}$. for one and a half hours and after enzymatic hydrolysis by $\beta$-glucuronidase showed no differences within the limits of accuracy of the chemical estimation. The results of these measurements are shown in Table III. Considering the comparatively용 low absolute concentration of p-aminophenol per: millilitre serum, the agreement between the values found by the two different modes of hydrolysis is

TABLE III

COMPARISON BETWEEN ESTIMATIONS OF TOTAL N.A.P.A. (FREE AND CONJUGATED) IN SERUM AFTER ACID HYDROLYSIS BY CONCENTRATED HCL AND AFTER ENZYMATIC HYDROLYSIS BY $\beta$ GLUCURONIDASE ${ }^{1}$

\begin{tabular}{|c|c|c|c|c|c|c|c|c|c|c|}
\hline \multirow[t]{3}{*}{ Name } & \multicolumn{5}{|c|}{ Acid Hydrolysis } & \multicolumn{5}{|c|}{ Hydrolysis by $\beta$ glucuronidase } \\
\hline & \multicolumn{5}{|c|}{ Hours } & \multicolumn{5}{|c|}{ Hours } \\
\hline & 1 & 2 & 4 & 7 & 9 & 1 & 2 & 4 & 7 & 9 \\
\hline $\begin{array}{l}\text { W.K. } \\
\text { M.H. } \\
\text { H.C. } \\
\text { B.D. } \\
\text { B.H. } \\
\text { G.S. } \\
\text { D.S. }\end{array}$ & $\begin{array}{l}18.0 \\
13.4 \\
33.4 \\
21.0 \\
31.0 \\
28.0 \\
23.0\end{array}$ & $\begin{array}{l}19 \cdot 0 \\
14.4 \\
31 \cdot 5 \\
22 \cdot 0 \\
25 \cdot 0 \\
24 \cdot 0 \\
18 \cdot 5\end{array}$ & $\begin{array}{c}16.6 \\
11.7 \\
25.4 \\
-\overline{18.0} \\
13.0 \\
15.5\end{array}$ & $\begin{array}{r}8.4 \\
6.5 \\
13.3 \\
10.5 \\
6.5 \\
4.5 \\
5.5\end{array}$ & $\begin{array}{l}4 \cdot 3 \\
3 \cdot 7 \\
9 \cdot 1 \\
6 \cdot 0 \\
4 \cdot 5 \\
2 \cdot 1 \\
1 \cdot 9\end{array}$ & $\begin{array}{l}13.5 \\
12.5 \\
39.0 \\
23.0 \\
29.5 \\
26.0 \\
26.6\end{array}$ & $\begin{array}{l}19.0 \\
15.0 \\
33.0 \\
22.0 \\
25.0 \\
23.0 \\
22.0\end{array}$ & $\begin{array}{c}16 \cdot 7 \\
11.5 \\
24.5 \\
-\overline{14.8} \\
13.0 \\
16.0\end{array}$ & $\begin{array}{r}5.7 \\
5.9 \\
13.8 \\
10.0 \\
5.0 \\
5.0 \\
7.0\end{array}$ & $\begin{array}{l}3.9 \\
3.0 \\
9.5 \\
5.0 \\
4.0 \\
2.8 \\
2.0\end{array}$ \\
\hline Average & 23.9 & $22 \cdot 0$ & 16.7 & $7 \cdot 8$ & $4 \cdot 5$ & $24 \cdot 3$ & $22 \cdot 7$ & $16 \cdot 1$ & $7 \cdot 5$ & $4 \cdot 3$ \\
\hline
\end{tabular}


obvious. From this it would appear that there is no other hydroxy-conjugate than glucuronide present in the serum. Contamination of the enzyme preparation with sulphatase, which at the same time would liberate sulphate conjugates, was ruled out. On the other hand, it is known that sulphuric acid conjugates of phenol and aminophenol are easily split by dilute acids (c.f. Levvy and Storey, 1949). Because acid is used in the procedure for the estimation of free N.A.P.A., the possibility exists that sulphate conjugates were measured along with free N.A.P.A. Studies are under way to investigate this question further. The same studies made with urine reveal the presence of a considerable amount of N.A.P.A. conjugates, which are not liberated by $\beta$ glucuronidase, and on examination by the method of Folin (1905) were found to be bound to sulphate. This confirms the findings of Greenberg and Lester (1946) and others. The tests done with conjugates in the urine can be regarded as further proof against the presence of sulphatases in the enzyme preparation used. There remains the question how and where the N.A.P.A. glucuronide in the serum is converted in part to N.A.P.A. sulphate. It seems likely that the kidney might play a role in this transformation.

It can be seen from the examples shown in Figs. 1 to 4 that there is a distinct difference in the speed at which the N.A.P.A. concentration declines in the blood. During the acute phase the decrease of free N.A.P.A. is slower than after recovery from hepatitis. Likewise the level of N.A.P.A. glucuronide during the disease remains below the one attained after cure. In Fig. 1 (an example of an oral test done with acetanilide) the peak concentration of free N.A.P.A. is reached later than in the case of oral or intravenous N.A.P.A. because the substance has first to be oxidized in the para position. As a con- sequence, conjugation to the glucuronide sets in later. But basically the same trend is evident as in the examples 2, 3, and 4, when N.A.P.A. was administered orally or intravenously. During the acute phase the concentration of N.A.P.A. in the serum declines more slowly and the curve of N.A.P.A. glucuronide is flatter than in the same children after recovery.

The high immediate peak value for N.A.P.A. glucuronide shown in Fig. 2 may well be due to more rapid conjugation when the N.A.P.A. is absorbed directly into the portal circulation than when administered intravenously: on the other hand, as wide variations in the rate of conjugation and the levels reached have been observed in different subjects, this cannot be regarded as proved.

In Table IV the amount of free N.A.P.A. present six hours after the intravenous injection of N.A.P.A., or seven hours after the oral administration of N.A.P.A. or acetanilide is expressed as a percentage of the N.A.P.A. level at the beginning of the test, or in the cases of oral administration, of the maximal concentration of N.A.P.A. reached during the experiment. With one exception, where there was no significant difference between the results of both tests, the percentage retention of N.A.P.A. was always higher in the acute phase than in the second study done after liver function had returned to normal. In Table IV the maximum concentrations of N.A.P.A. glucuronide in $\mu \mathrm{g} . / \mathrm{ml}$. are listed separately for the two studies done on each patient. Again, with the exception of the child who showed no difference in the percentage of N.A.P.A. retained, all the patients had higher values during the second test, i.e., the curve of N.A.P.A. glucuronide in the serum took a flatter course during hepatitis than it does normally.

TABLE IV

RETENTION OF FREE N.A.P.A. IN SERUM DURING AND AFTER HEPATITIS

\begin{tabular}{|c|c|c|c|c|c|c|}
\hline \multirow[t]{2}{*}{ Name } & \multirow[t]{2}{*}{ Age $(y r)}$. & \multirow[t]{2}{*}{$\begin{array}{l}\text { Dose Administered } \\
\text { (mg./kg. body weight) }\end{array}$} & \multicolumn{2}{|c|}{$\begin{array}{l}\% \text { Retention After Six and } \\
\text { Seven Hours }\end{array}$} & \multicolumn{2}{|c|}{$\begin{array}{l}\text { Peak Level }(\mu g . / m l .) \text { of N.A.P.A. } \\
\text { Glucuronide in Serum }\end{array}$} \\
\hline & & & First Test & Second Test & First Test & Second Test \\
\hline $\begin{array}{l}\text { T.A. } \\
\text { M.H. } \\
\text { R.M. } \\
\text { N.C. } \\
\text { K.V. } \\
\text { K.A. }\end{array}$ & $\begin{array}{r}7 \\
10 \\
15 \\
5 \\
12 \\
14\end{array}$ & $\begin{array}{c}\text { N.A.P.A. intravenously } \\
10 \\
10 \\
10 \\
20 \\
20 \\
20\end{array}$ & $\begin{array}{r}14 \\
3 \cdot 2 \\
26 \cdot 8 \\
9 \cdot 5 \\
14 \cdot 8 \\
16 \cdot 5\end{array}$ & $\begin{array}{r}11 \cdot 9 \\
4 \cdot 7 \\
8 \cdot 4 \\
8 \cdot 5 \\
11 \cdot 6 \\
8.0\end{array}$ & $\begin{array}{l}1.6 \\
5.4 \\
4 \cdot 5 \\
7 \cdot 4 \\
6.0 \\
6.6\end{array}$ & $\begin{array}{l}4 \cdot 5 \\
3 \cdot 9 \\
6 \cdot 0 \\
7 \cdot 8 \\
7 \cdot 7 \\
9 \cdot 1\end{array}$ \\
\hline G.S. & 7 & $\begin{array}{c}\text { N.A.P.A. orally } \\
20\end{array}$ & $11 \cdot 7$ & 5.8 & $10 \cdot 2$ & $15 \cdot 0$ \\
\hline $\begin{array}{l}\text { F.R. } \\
\text { S.N. }\end{array}$ & 10 & $\begin{array}{c}\text { Acetanilide orally } \\
20 \\
20\end{array}$ & $\begin{array}{l}54 \\
26\end{array}$ & $\begin{array}{l}21 \\
9 \cdot 5\end{array}$ & $\begin{array}{l}1.7 \\
1.8\end{array}$ & $\begin{array}{r}7 \cdot 1 \\
17 \cdot 2\end{array}$ \\
\hline
\end{tabular}



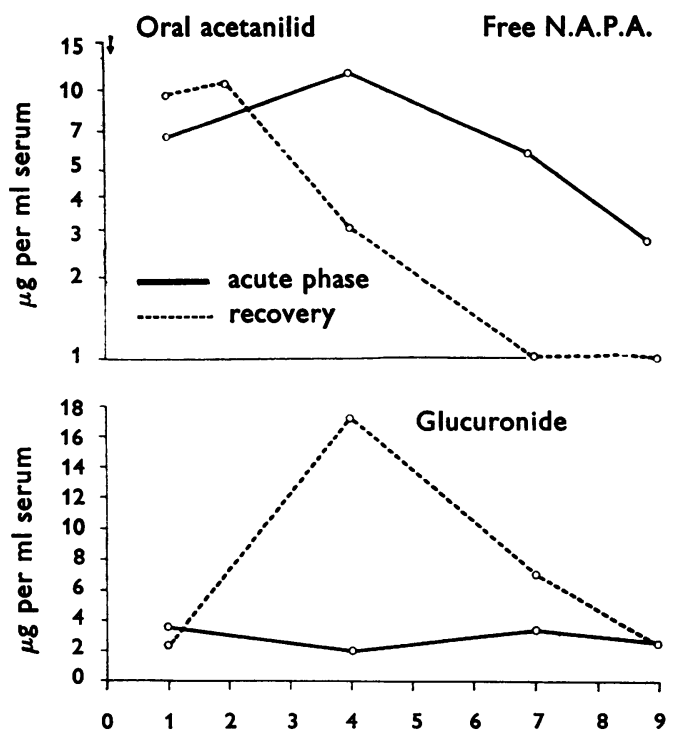

Hours after administration of acetanilid

FIG. 1. S.N., aged 10 years. Disappearance of free N.A.P.A. and formation of N.A.P.A. glucuronide in the serum during hepatitis and after recovery. Oral administration of acetanilide, $20 \mathrm{mg}$. per $\mathrm{kg}$. body weight.

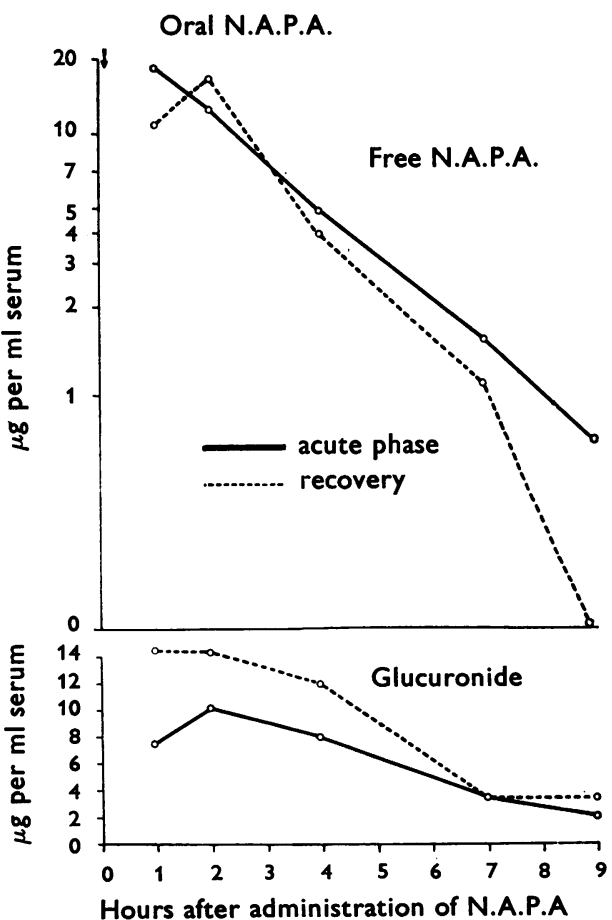

FIG. 2. G.S., aged 7 years. Disappearance of free N.A.P.A. and formation of N.A.P.A. glucuronide in the serum during hepatitis and after recovery. Oral administration of N.A.P.A., $20 \mathrm{mg}$. per kg. body weight.
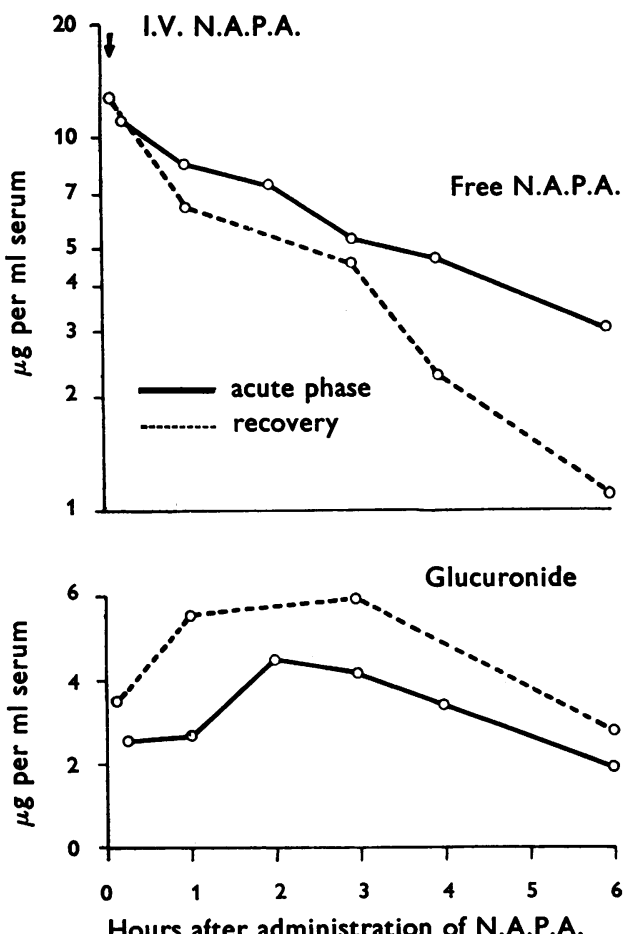

FIG. 3. R.M., aged 15 years. Disappearance of free N.A.P.A. and formation of N.A.P.A. glucuronide during hepatitis and after recovery. Intravenous injection of N.A.P.A., $10 \mathrm{mg}$. per kg. body weight.

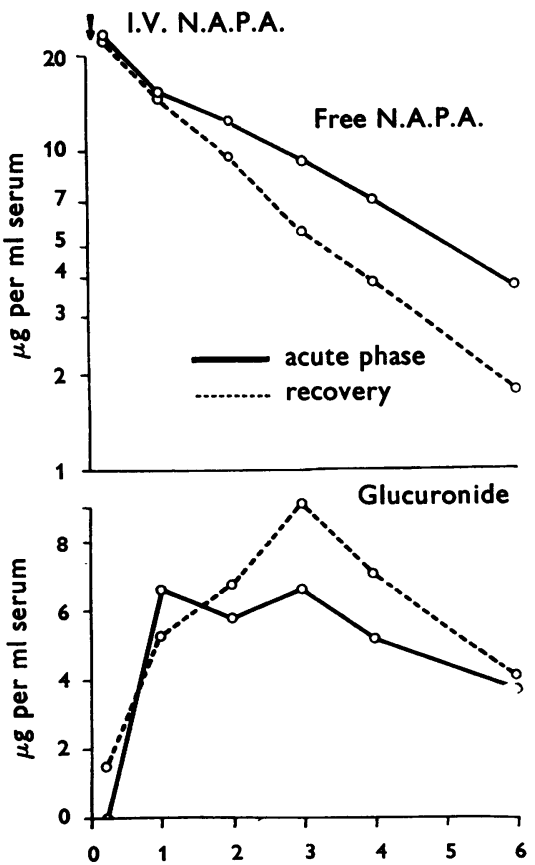

Hours after administration of N.A.P.A.

FIG. 4. K.A., aged 14 years. Disappearance of free $e_{\varrho}^{\overparen{\Phi}}$ N.A.P.A. and formation of N.A.P.A. glucuronide in the serum during hepatitis and after recovery. Intravenous injection of N.A.P.A., $20 \mathrm{mg}$. per kg. body weight. 


\section{DISCUSSION}

In these studies we have shown that the urinary elimination of N.A.P.A. or acetanilide is diminished during viral hepatitis. The reduction in excretion of a given dose amounted on the average to $20 \%$ of the values found in the same individuals after recovery, with a variation from $10 \%$ to $37 \%$. This reduction is reflected also in the values found for individual conjugates. The glucuronides, i.e., that part of the hydroxy conjugates liberated by the action of $\beta$ glucuronidase, decreased, especially during hepatitis, and showed a subsequent increase. Less consistent was the behaviour of sulphate conjugates. A distinct increase was seen only in the patients who received a dose of $20 \mathrm{mg}$. per kg. body weight of N.A.P.A. but not in the group receiving $10 \mathrm{mg}$. per $\mathrm{kg}$. No clear trend was discernible with regard to free N.A.P.A. in urine, though on theoretical grounds one could perhaps have expected an increase of free N.A.P.A. when the conjugation mechanism is disturbed. Such an increase was seen only in the three cases receiving $20 \mathrm{mg}$. per $\mathrm{kg}$. body weight of N.A.P.A. and even in these free N.A.P.A. contributed only a small percentage of the total.

The observed reduction in the excretion of a load of N.A.P.A. may result from a disturbance of the conjugation at the hydroxyl group. Even though we know of no reports of disturbance of kidney function in hepatitis, a failure of the kidneys to excrete the substance might, in principle, also cause a reduction in percentage excretion. If conjugation is disturbed one would expect a lower disappearance rate of free N.A.P.A. from the blood because of diminished hepatic transfer and low levels of N.A.P.A. conjugates. A diminished excretion on the other hand would lead to an accumulation of the conjugated product. An examination of N.A.P.A. and its metabolites in the serum would permit a distinction between these possibilities.

From the examples given in Figs. 1 to 4 and from the values in Table IV it can be seen that such a reduction in the disappearance rate of free N.A.P.A. is observed in the patients tested. Furthermore, glucuronide levels were lower than in the same individuals after recovery. From this a diminished renal clearance during hepatitis can be ruled out. There seems to be no doubt that the reduction in excretion of N.A.P.A. and the low levels of N.A.P.A. conjugates observed during hepatitis are the results of a disturbance in glucuronide formation. This then from a different approach confirms the findings of Billing (1955b), Bollmann (1959), and others of a decreased formation of bilirubin diglucuronide. The findings are also consistent with the wellsubstantiated fact of a diminished conjugation with glycine, as in hippuric acid formation (Quick, 1933) and in other transformation reactions (Snapper and Saltzman, 1949) during hepatitis.

\section{REFERENCES}

Billing, B. H. (1955a). J. clin. Path., 8, 126.

- (1955b). Ibid, 8, 130.

, Cole, P. G., and Lathe, G. H. (1957). Biochem. J., 65, 774.

, and Lathe, G. H. (1958). Amer. J. Med., 24, 111.

Bollman, J. L. (1957). In F. W. Hartman, Hepatitis Frontiers, p. 467. Little, Brown, Boston. (1959). Gastroenterology, 36, 1313.

Brodie, B. B., and Axelrod, J. (1948). J. Pharmacol. exp. Ther., 94, 22.

Dische, Z. (1947). J. biol. Chem., 167, 189.

Eberlein, W. R. (1960). Pediatrics, 25, 878.

Fisher, R. A. (1954). Statistical Methods for Research Workers, 12th ed. Oliver and Boyd, Edinburgh.

Folin, O. (1905). J. biol. Chem., 1, 131.

Greenberg, L. A., and Lester, D. (1946). J. Pharmacol. exp. Ther., 88, 87.

Levvy, G. A., and Storey, I. D. E. (1949). Biochem. J., 44, 295.

Quick, A. J. (1933). Amer. J. med. Sci., 185, 630.

Schachter, D. (1959). J. Lab. clin. Med., 53, 557.

Snapper, I., and Saltzman, A. (1949). Arch. Biochem., 24, 1.

Vest, M. F. (1958). Arch. Dis. Childh., 33, 473.

-, and Streiff, R. R. (1959). Amer. J. Dis. Childh., 98, 688. 